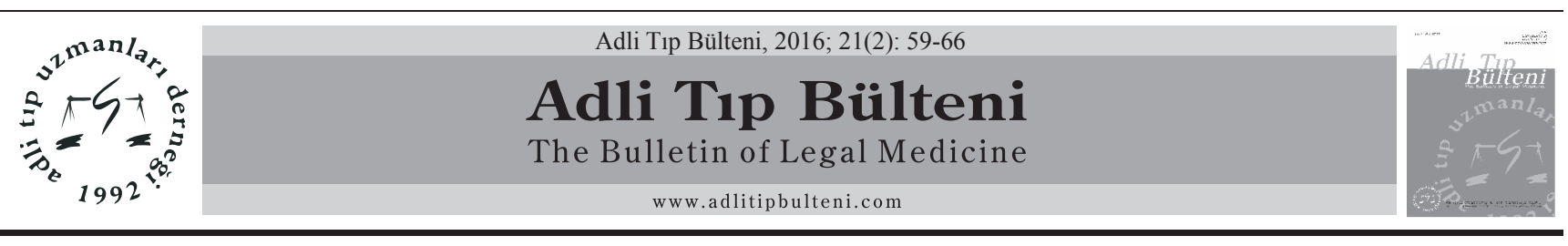

\title{
Suçların Aydınlatılmasında CSI Etkisi
}

\section{CSI Effect of Crime Clarification}

\author{
Aylin Yakupoğlu, Can Çalıcı, Neylan Ziyalar \\ İstanbul Üniversitesi Adli Tip Enstitüsü, İstanbul
}

\section{Özet}

Amaç: $\mathrm{Bu}$ araştırma, CSI ve benzeri dizilerin adalet sistemi çalışanlarının tutum ve davranışları ile toplum üzerindeki etkisinin değerlendirilmesini amaçlamaktadır. $\mathrm{Bu}$ bağlamda araştırmada bir suçun faili olabilecek kişilere CSI ve benzeri dizilerin ne denli yol gösterici olduğu, adalet mekanizmasının farklı alanlarında çalışanların mesleklerini icra etmeleri sırasında toplumun beklentilerinin ne yönde değiştiği ve bu yapımların adli bilimler konusunda gerçekçi bir tutum sergileyip sergilemedikleri hakkındaki sorulara yanıt aranmıştır.

Gereç ve Yöntem: Araştırma, 2011-2012 yıllarında İstanbul'da, adli mekanizmanın çeșitli alanlarında hizmet veren polis, adli bilim/tıp uzmanı, serbest avukat, Ceza Mahkemeleri'nde görevli hakim ve Cumhuriyet Savcısı'ndan oluşan toplam 266 kişiyi kapsayan bir anket çalışması ile gerçekleştirilmiştir. Anket sonucunda elde edilen veriler SPSS (Versiyon 20.0) kullanılarak analiz edilmiş ve değerlendirilmiştir.

Bulgular: Araştırmanın bazı önemli sonuçlarına göre; her 2 adli mekanizma çalışanından 1'i CSI dizilerini takip etmektedir. Her 10 katılımcıdan yalnızca 3'ü bu dizilerin mesleki uygulamalarını olumlu etkilediğini düşünürken, anketimizi yanıtlayanların yarısından fazlası söz konusu programların suçlu davranışını değiştirdiğini ve eğitimli failler yarattığ fikrine destek vermişlerdir. Her 2 katılımcıdan 1'i bu dizilerin etkisiyle şüpheli ve sanıkların olay yerinde daha az delil bıraktıklarını düşünmektedir.

Sonuç: Suçun aydınlatılmasına yönelik adli bilimsel yöntem ve tekniklerin ekranlarda gerçek dışı bir şekilde izleyiciyle buluşmasının, toplumun adalet mekanizmasından beklentilerini değiştirdiği görülmektedir. Bu bağlamda adalet sistemiyle ilk kez karş1 karşıya gelen bir vatandaşın soruşturma ve kovuşturma sürecine dair yanlış algılara sahip olabileceği düşünülmektedir.

Anahtar Kelimeler: CSI Etkisi; Olay Yeri İnceleme; Adli Bilimsel Yöntem ve Teknikler.

\section{Abstract}

Objective: This research is aimed to evaluate the impact of CSI series on Criminal Justice Professional's attitudes and behaviour and how these programs are affecting the public. From this point of view criminal justice professionals are expected to respond questions about, how this kind of dramas and programs advised potential criminals, reflected the practice of forensic science and directed the public expectation regarding performing their professions.

Materials and Methods: A survey has been conducted to 266 participants, who are working as crime scene investigation specialists, criminal courts judges, public prosecutors, lawyers, law enforcement personnel and forensic specialists, to reveal their perceptions. Gained data has been analyzed statistically by using SPSS (Version 20.0).

Findings: According to some results of the research; 1 out of every 2 participants are following CSI series. Only 3 out of every 10 participants expressed that these kind of series have positive effects on their professional practices, more than half of the participants agreed that crime dramas are effecting criminal behaviour and creating trained perpetrators. Also 1 out of every 2 participants believe that the perpetrators are attentive to leave fewer evidence because of these programs.

Results: CSI series are not reflecting forensic techniques and methods as what it's supposed to be in real life. Due to the raise of public interest in forensic sciences because of these dramas people changed their expectation about criminal justice mechanism which can cause misperceptions on citizens who face with investigation and prosecution processes for the first time

Keywords: CSI Effect; Crime Scene Investigation; Forensic Techniques and Methods.

\section{Giriş}

Polisiye dizileri 1950'lerden beri dünya televizyonlarında yayınlanmaktadır (1). Crime Scene Investigation (CSI; Olay Yeri İnceleme) dizileri, suç failini/faillerini

Sorumlu Yazar: Doç.Dr. Neylan Ziyalar

İstanbul Üniversitesi Adli Tip Enstitüsü, İstanbul

E-posta:neylan@istanbul.edu.tr

Geliş: 17.03.2016 Düzeltme: 02.05.2016 yakalama konusunda adli bilimsel teknik ve yöntemlerin merkez rol oynadığı yeni nesil polisiye dizilerdir (2). Amerika Birleşik Devletleri'nde Nielsen Media Research tarafından yapılan araştırmaya göre, bir gece içinde bu tür dizileri izleyenlerin sayısı yaklaşık otuz milyonu bulmaktadır (3). 2000'li yılların başında ekranlarda yer almaya başlayan CSI dizileri bugün, dünyanın en popüler dizileri haline gelmiştir (4). CSI LA, CSI Newyork, CSI Miami, 
Dexter, Cold Case, Criminal Minds, Without a Trace içeriğinde adli bilimsel teknik ve yöntemleri barındıran bu tür dizilerin dünyaca ünlü örneklerindendir. Olay yeri inceleme araştırmasını ve adli bilimler sürecini konu alan bu dizilerin popülaritesinin artması birçok ülkede çeşitli versiyonlarının çekilmesini de beraberinde getirmiştir. Ülkemizde ise 2010 yılında yayımlanmaya başlayan "Kanıt” dizisi bu tür dizilerin başlıca örneklerindendir.

Yapılan araştırmalar, 2000'li yıllardan bu yana CSI dizilerinin etkisiyle medyanın suça ve suçun çözümüne ilişkin ilgi ve bilgisinin arttığını ortaya koymaktadır. Bu durum, aynı zamanda adli bilimlere ilişkin toplumsal bir farkındalığı ve beklentiyi de işaret etmektedir. CSI dizilerinde sunulan temalar, suçun teknoloji ile birlikte kolayca çözülebileceği yönündedir ve suçun aydınlatılmasına yönelik yöntemlerle ilgili beklentilerin yanlış bir biçimde yükselmesine sebep olduğu düşünülmektedir. Bu tür yapımlar, adli bilimsel yöntem ve tekniklerin kendi gerçekliği ve sınırları ile ilgili birçok mitin varlığına imza atmıştır (5). Bu durum adli bilimler literatürüne "CSI Etkisi" olarak geçmiş ve yeni tartışmaların doğmasına zemin hazırlamıştır. CSI Etkisi, televizyon dizilerinde adli bilimsel yöntemlerin toplum üzerinde yanlış kanı ve inançlar oluşturabilecek şekilde abartılı bir biçimde kullanılması sonucunda ortaya çıkan etkidir (6). CSI Etkisi terimi ilk kez 2002'de CBS Early Show ve Time Magazine'de bir makalede yer almıştır (7). 2003 yılında Amerikan hukuk sözlüklerine dahil olmuştur (8). 2003 ve 2004 'de akademik ve kamusal alanda kullanımı artarken 2005 yılı itibariyle artık her kesimin konuya olan ilgisinin arttığ gözlemlenmektedir $(7,9,10)$.

Suçların aydınlatılmasına ve adli işleyişe yönelik toplumun bilgisi ve inanç kalıpları, televizyon başta olmak üzere diğer farklı medya organlarında anlatılanlar ve gösterilenler tarafindan belirlenmektedir. Amerika Birleşik Devletleri'nde suç haberleri hakkında yapılan bir araştırmada, katılımcıların \%76'sı suç konusundaki fikirlerini televizyondan edindiklerini ifade etmiştir (11). Bu oran, suça dair bilgilerini ilk elden edindiklerini belirtenlerin (\%22) üç katından daha fazladır. CSI ve benzeri dizilerin izlenme oranları göz önünde bulundurulduğunda, izleyici kitlenin adli bilimler ve adalet sisteminin işleyişine dair sahip oldukları bilginin büyük ölçüde bu tür televizyon programlarında sunulanlardan kaynakladığı söylenmektedir. "CSI Etkisi” Anglo-Sakson hukuk sistemlerinde jüri üyelerinin CSI dizisini izlemelerinin yarattığı etkiyi anlatmak için de kullanılmıştır (7). Buna göre, jüri üyeleri yargılama sırasında kendilerini sanığın suçlu olduğuna ikna edecek yeterli adli bilimsel delil bulunmadığını düşünmekte ve gittikçe daha fazla sanığın beraatine karar vermektedir (12). Zaman içinde jüri üyeleriyle sınırlı ol- madığ 1 anlaşılan bu etki, "adli bilimlerin televizyondaki karşılığının toplumda oluşturduğu yanılmazlık algısı" olarak geniş kitlelere yayılmıştır (8).

CSI dizilerinde adli bilimler sürükleyici, eğlenceli ve izleyiciye çekici gelecek şekilde kurgulanmıştır. Bu kurgu henüz var olmayan bilimsel yöntemler ve bilimsel yöntemlerin gerçek dışı bir hızla sonuç vermesi üzerine kurulmuştur (13). CSI dizilerinde olay yeri inceleme ve olay yerinden elde edilen delillerin değerlendirilmesi izleyiciye bir tür bilimsel sihirbazlık ve adli bilimlerin her alanını kapsayan "süper dedektiflik" olarak sunulmaktadır (7). Her ne kadar dizilerde izleyiciye sunulan içerikle, adli bilimsel yöntem ve tekniklere dair gerçeklik birbiriyle zaman zaman örtüşse de özünde önemli farklılikları da barındırmaktadır (Bkz. Tablo 1). En temel farklılıklardan birinin zamansal anlamda yapılan çarpıtmalar olduğu düşünülmektedir. Dizilerin kurgusal dünyasında laboratuvar sonuçlarına hatasız bir şekilde ve yalnızca dakikalık bir zaman dilimi içerisinde ulaşılabilirken, gerçekte bu sonuçlara ulaşmak haftalarca hatta bazen aylarca sürebilmektedir (2). Diğer bir yandan bu tür dizilerde incelenen olay yerlerinde, olay yeri inceleme ekiplerinin bulduğu her ipucu suça ilişkin ve fazla sayıda olup delil niteliğindedir. Çok kısa bir zaman zarfinda toplanan bu deliller, gerçek ya da kurgusal enstrümanlarla hemen analiz edilmektedir (14). Ancak gerçekte, CSI dizilerinde kullanılan bilimin \%40'1 neredeyse hiçbir gerçekliğe sahip değildir. Geriye kalan kısım ise laboratuvar personeli için ancak hayal olabilecek yöntemlere dayanmaktadır $(15,16,17)$.

CSI ve benzeri dizilerin herkes tarafindan izlendiği bir sır değildir ve "herkes" kavramının içine ciddi suçlar işleyen ve işleyecek olan kimseler de girmektedir. Pek çok insan, CSI Etkisinin en ciddi yanının, suç işleme potansiyeli taşıyanların bu programları izleyerek bilgilenmesi olduğunu iddia etmektedir (5).

Son yıllarda Türkiye'de işlenen kimi adam öldürme suçlarında da CSI dramalarının bu etkisini çağrıştıran detaylara rastlanmaktadır. Söz gelimi, Eylül 2013 tarihinde Zonguldak'ın Ereğli ilçesinde yaşanan cinayette fail G.T.'nin ellerini bileklerinden kesmiş, kesilen ellerle birlikte elbiselerinin de kayıp olduğu ortaya çıkmıştır. Savcılık makamı katilin delil bırakmamak için genç kızı öldürdükten sonra kestiği ellerini ve elbiselerini alıp götürdüğünü iddia etmiş, söz konusu cinayetle ilgili basinda yer alan haberlerde de failin delilleri yok etmeye çalışması üzerinde durulmuştur (18).

Dünyada CSI Etkisini gözlemleyen araştırmaların pek çoğu özellikle adalet sisteminde çalışan uzmanların konuyla ilgili görüşlerine odaklanmaktadır $\mathrm{Bu}$ sebeple ülkemizdeki adalet profesyonellerinin de sözü edilen 
Tablo 1. CSI dramalarında kullanılan adli bilimsel yöntem ve teknikler ile gerçekte kullanılan adli bilimsel yöntem ve teknikler arasındaki farklılıkların karşılaştııılması (17).

\begin{tabular}{|l|l|l|}
\hline & CSI'da Kullanılan Yöntemler & Adli Bilimlerde Kullanılan Yöntemler \\
\hline $\begin{array}{l}\text { Adli Kimlik } \\
\text { Tespiti }\end{array}$ & $\begin{array}{l}\text { Suçlularla görüşüp kanıtları toplayan } \\
\text { ve analiz edenler bilim adamlarıdır. }\end{array}$ & Öncelikli işi delil toplamak olan polis memurlarıdır. \\
\hline Adli Kimya & $\begin{array}{l}\text { Tekniklerin doğruluğu ve } \\
\text { kullanılabilirliği abartılmıştır. }\end{array}$ & CSI ile aynı tekniklerdir ama kesinliği daha azdır. \\
\hline Adli Biyoloji & $\begin{array}{l}\text { Olay yerinde çok fazla biyolojik } \\
\text { delile hızla ulaşılmaktadır. }\end{array}$ & $\begin{array}{l}\text { Biyolojik delilleri analiz etmek çok fazla zaman } \\
\text { almaktadır ve bu deliller olay yerinde daha az } \\
\text { bulunmaktadır. }\end{array}$ \\
\hline $\begin{array}{l}\text { Adli } \\
\text { Toksikoloji }\end{array}$ & $\begin{array}{l}\text { Maddelerin içeriği tek bir test ile } \\
\text { belirlenebilmektedir. }\end{array}$ & $\begin{array}{l}\text { Ancak birçok test sonucunda maddenin içeriğine } \\
\text { ulaşılabilmektedir. }\end{array}$ \\
\hline Sorgu Belgeleri & $\begin{array}{l}\text { Yazı stilinden bireylerin kişilik } \\
\text { özellikleri bulunabilmektedir. }\end{array}$ & $\begin{array}{l}\text { Kişilik özelliklerini elde etmek soruşturmanın bir parçası } \\
\text { değildir. }\end{array}$ \\
\hline $\begin{array}{l}\text { Balistik ve Alet } \\
\text { İzleri }\end{array}$ & $\begin{array}{l}\text { Bulunan izin hangi aletten geldiğine } \\
\text { karar verilebilmektedir. }\end{array}$ & Daha fazla zaman alması haricinde benzerdir. \\
\hline Adli Patoloji & $\begin{array}{l}\text { Adli patologlar diğer uzmanlara } \\
\text { ihtiyaç duymaz. }\end{array}$ & Adli patologlar diğer uzmanlara ihtiyaç duyar. \\
\hline $\begin{array}{l}\text { Adli } \\
\text { Entomoloji }\end{array}$ & $\begin{array}{l}\text { Yüzeysel bir inceleme ile ceset } \\
\text { üzerindeki böceklerden yola çıkarak } \\
\text { ölüm saatine karar verebilmektedir. }\end{array}$ & Larvalar yetişkinliğe ulaşmış olmalıdır. \\
\hline
\end{tabular}

durumdan nasıl etkilendiklerine dair bir araştırmanın gerekli olduğu düşünülmüştür. Bu çalışma CSI ve benzeri dizilerin Türkiye'de, hâkimler, savcılar, avukatlar, adli bilim uzmanları, polisler ve toplum üzerindeki etkisini analiz etmeyi amaçlamaktadır. Bu doğrultuda yukarıda sözü edilenler dikkate alınarak, CSI etkisinin adalet mekanizmasını hangi yönlerden etkilediğini, toplumun bu yöndeki farkındalığını ve adli bilimlere karşı geliştirdiği beklentilerini ortaya çıkarmak; bu formattaki programların ve dizilerin adalet sistemi profesyonellerini mesleki anlamda nasıl ve hangi yönlerden etkilediğini analiz etmek hedeflenmektedir.

\section{Gereç ve Yöntem}

Bu çalışma 2011-2012 yıllarında İstanbul'da, adli mekanizmanın çeşitli ayaklarında görev alan beş fark11 meslek grubundan toplam 266 kişi ile gerçekleştirilmiştir. Katılımcıların 128'i İçişleri Bakanlığı Emniyet Genel Müdürlügüü kapsamında görev yapan polis, 52'si adli bilim/tıp uzman1, 35'i serbest avukat, 30'u ceza mahkemelerinde görevli hakim, 21'i Cumhuriyet Savcısıdır. Söz konusu kişilere CSI dizilerinin bireyler üzerindeki etkilerini belirlemek amaciyla Kanada Saint Mary Üniversitesi'nden Stinson, Patry ve Smith tarafindan üretilen "CSI Etkisi" ölçeği uyarlanmak suretiyle uygulanmıştır (19). Ölçüm aracı ilk olarak iki bağımsız uzman tarafından Türkçe'ye çevrilmiştir ve anlam bakımından uygun bulunan ifadeler dahil edilmiştir. Bu işlemin ardın- dan ölçüm aracının ölçüm özelliğini test edebilmek için 20 kişilik pilot çalışma yapılmıştır. Yapılan analizler sonucu bu ölçüm aracının Türkçe olarak anlaşıldığı ve "CSI Etkisi"ni ölçümleyebildiği sonucuna ulaşılmıştır.

Veri toplama yüz yüze görüşme yöntemi ile gerçekleştirilmiştir. Kullanılan ölçek, toplam 17 sorudan oluşmaktadır ve katılımcıların kişisel görüş ve tutumlarının öğrenilmesi amaçlandığı için beşli Likert tipi derecelendirilmiştir.

Ölçekle elde edilen veriler SPSS 20.0 ile analiz edilmiştir. Hipotezlerin test edilmesinde, data yapısının uygunluğu doğrultusunda parametrik testler kullanılmış; grupların karşılaştırılmasında t-testi ve ANOVA (Varyans Analizi) analiz yöntemlerinden faydalanılmıştır. Ayrıca, ölçeğin güvenilirliği için Cronbach's Alpha değeri analiz edilmiş ve $\alpha=, 657$ olarak tespit edilmiştir.

\section{Bulgular}

Araştırmaya katılanların cinsiyet dağılımına bakıldığında katılımcıların yaklaşık 4'de 1'inin kadın, 4'de 3'ünün erkek olduğu anlaşılmaktadır. Her 10 katılımcıdan 1'i 20-25 yaş grubunda, 4'ü 26-30 yaş grubunda, 2'si 31-35 yaş grubunda, 3'ü ise 35 ve üzeri yaş grubunda olduğu ortaya çıkmaktadır.

Araştırmaya katılanların CSI izleme durumlarına göre dağılımlarına bakıldığında yaklaşık her 2 katılımcıdan 1'i bu yapımları takip ettiğini, her 10 katılımcıdan 1 'i ise hiç izlemediğini belirtirken, 4'ü ise CSI dizilerini arada sırada izlediklerini ifade etmişlerdir. CSI izleme sıklıklarının 
dağılımlarına bakıldığında ise her 10 katılımcıdan 3'ü haftada 1-2 kez izlerken, 2'si haftada 2-3 kez, yine 2' si haftada 3-4 kez veya daha fazla izlemektedir. Katılımc1ların 3'de 1'inin ise CSI dizilerini ayda bir kez izledikleri ortaya çıkmaktadır.

Anketin sonuçlarına göre sözü edilen yapımları izleyenlerin öncelikle yerli yapımları takip ettikleri anlaşılmaktadır. Buna göre her 2 katılımcıdan 1'i; Behzat Ç., Kanıt ve Arka Sokaklar yapımlarını izlemekteyken; her 3 katılımcidan 1' ise Dexter isimli yabancı diziyi takip etmektedir. Meslek gruplarına göre izlenen dizilerin dağılımına bakıldığında adli bilim/ tıp uzmanlarının ve hakimlerin Dexter'1, savcıların Kanıt ve Behzat Ç'yi, avukatların Kanıt'ı, polislerin ise Behzat Ç.'yi öncelikle takip ettikleri ortaya çıkmaktadır.

Katılımcılara bilim ve teknolojideki gelişmelerin suçların aydınlatılması yönünde olumlu bir etkiye sahip olup olmadığı sorulmuştur. Bu soruya verilen yanıtlar neticesinde her 10 katılımcıdan 8 'i bu gelişmelerin suçların aydınlatılmasında olumlu rol oynadığı yönünde fikir beyan ederken, 2'si bu konuda kararsız kaldığını ve olumlu bir etkinin olmadığını savunmuştur (Tablo 2). Bu konuda olumlu fikir beyan edenlerin meslek gruplarına göre dağılımına bakıldığında; sırasıyla hakimler, avukatlar, savcılar, polisler ve adli bilim/tıp uzmanlarının geldiği görülmektedir (Şekil 1).

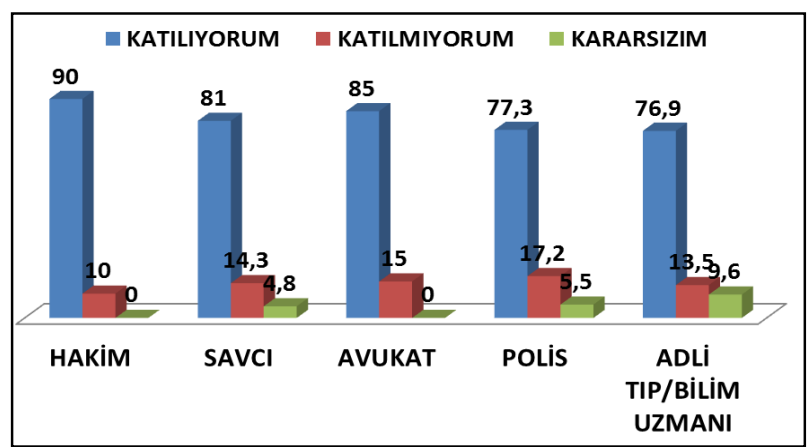

Şekil 1. Bilim ve Teknolojideki Gelişmelerin Suçların Aydınlatılmasına Etkisi (\%).

CSI yapımlarının soruşturdukları davalardaki uygulamaları olumlu yönde etkileyip etkilemediği sorulduğunda her 10 katılımcıdan 4'ü kararsız olduğunu beyan ederken, 3'ü olumlu, kalan 3'ü de olumsuz yönde görüş bildirmektedir (Tablo 2) Olumsuz görüş bildirenlerin meslek gruplarına göre dağılımınına bakıldığında sırasıyla hakimler, savcılar, adli tıp/ bilim uzmanları, avukatlar ve polisler gelmektedir.

Anketi cevaplayanların 4'de 3'ü CSI dizileri sayesinde toplumun mesleklerine olan ilgisinin arttığını belirtmiş, kalan 4'de 1'i bu fikre katılmamıştır (Tablo 2).
Kamunun adalet hizmetleri profesyonellerinin çalışma alanları ile ilgili beklentilerinin CSI dizileri dolayısıyla olumlu yönde değişip değişmediği yönündeki görüşü her 10 katılımcının 6'sı desteklerken, 2'si kararsız kalmış, 2'si ise haklı bulmadığını beyan etmiştir. (Tablo 2).

Katılımcıların yarısından fazlası CSI dizilerinin eğitimli fail yarattı̆̆ hususundaki görüşe katıldıklarını belirtirken 4'de 1'i bu konuda kararsız kalmıştır. Katılımcıların kalan 4'de 1'i ise bu görüşe katılmadıklarını belirtmişlerdir (Tablo 2). Bu konuda olumlu fikir beyan edenlerin sirasılla adli tıp/ bilim uzmanları, polisler, avukatlar, hakimler ve savcılar olduğu anlaşılmaktadır (Şekil 2).

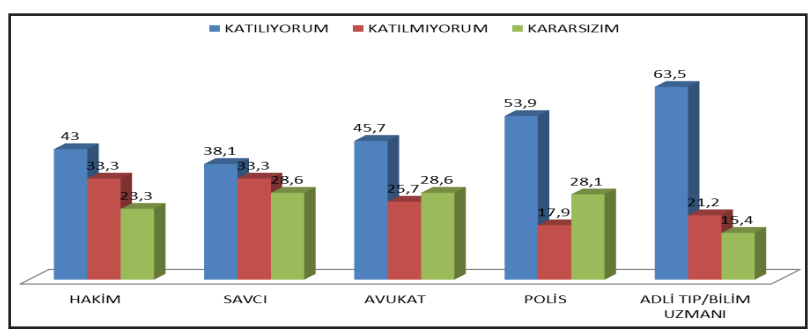

Şekil 2. CSI Dizilerinin Eğitimli Fail Yarattığına Dair Görüşlerin Dağılımı (\%).

CSI dizilerinin toplumda hukuk sisteminin işleyişi ile ilgili yanlış algıların oluşmasına yol açtığı yönündeki görüşe katılımcıların yarıya yakını katıldıklarını beyan ederken, 4'de 1'i bu konuda kararsız olduklarını, kalan 4'de 1'i de katılmadıklarını söylemişlerdir (Tablo 2). Bu görüşen katılanların yüzde dağılımına bakıldığında birinci sırada hakimler yer alırken, hakimleri sırasıyla adli tıp/ bilim uzmanları, avukatlar, polis ve savcılar izlemektedir.

Katılımciların 3'de 1'i bu yapımların olay yerinden delil toplamayı aslına uygun olarak gösterdiğini savunurken, kararsız kalanlar ve bu görüşe katılmayanların sayısı da bu orana yakındır. Adli tıp/ bilim uzmanları CSI dizilerinin olay yerinden delili toplamayı aslına uygun olarak lanse ettiklerini savunanların başında gelirken, bu konuda olumlu görüş beyan eden adli tıp/ bilim uzmanlarını sırasıyla polisler, savcılar, avukatlar ve hakimler takip etmektedir (Şekil 5).

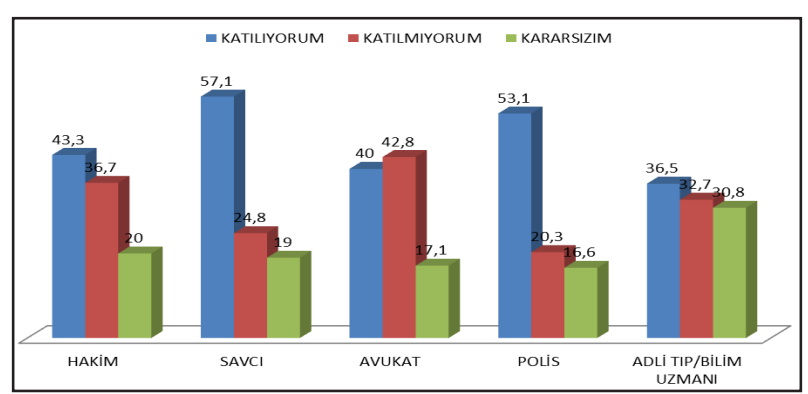

Şekil 3. CSI Dizilerinin Etkisiyle Şüpheli ve Sanıkların Eskiye Kıyasla Daha Az Delil Bıraktıklarına Dair Görüşlerin Dağılımı. 
Tablo 2. Önermelere Ait Frekans ve Yüzdeler.

\begin{tabular}{|c|c|c|c|c|c|c|c|c|c|c|}
\hline \multirow[t]{2}{*}{ Anket Soruları } & \multicolumn{2}{|c|}{$\begin{array}{l}\text { Kesinlikle } \\
\text { Katılıyorum }\end{array}$} & \multicolumn{2}{|c|}{ Katılıyorum } & \multicolumn{2}{|c|}{$\begin{array}{l}\text { Katılıyorum } \\
\text { Katılmıyorum }\end{array}$} & \multicolumn{2}{|c|}{ Katılmıyorum } & \multicolumn{2}{|c|}{$\begin{array}{l}\text { Kesinlikle } \\
\text { Katılmıyorum }\end{array}$} \\
\hline & f & $\%$ & $\mathbf{f}$ & $\%$ & f & $\%$ & f & $\%$ & f & $\%$ \\
\hline $\begin{array}{l}\text { Bilimsel ve teknolojideki gelişmeler } \\
\text { suçların aydınlatılmasını olumlu } \\
\text { yönde etkiledi. }\end{array}$ & 159 & 59,8 & 54 & 20,3 & 13 & 4,9 & 16 & 6,0 & 24 & 9,0 \\
\hline $\begin{array}{l}\text { CSI dizileri mesleki uygulamalarımızı } \\
\text { olumlu etkiledi. }\end{array}$ & 25 & 9,4 & 59 & 22,2 & 96 & 36,1 & 52 & 19,5 & 34 & 12,8 \\
\hline $\begin{array}{l}\text { CSI dizileri toplumun mesleğimize } \\
\text { olan ilgisini arttırdı }\end{array}$ & 84 & 31,6 & 116 & 43,6 & 38 & 14,3 & 22 & 8,3 & 6 & 2,3 \\
\hline $\begin{array}{l}\text { Kamunun çalışma alanımla ilgili } \\
\text { beklentileri CSI dizilerinden dolayı } \\
\text { değişti. }\end{array}$ & 45 & 16,9 & 97 & 36,5 & 73 & 27,4 & 33 & 12,4 & 18 & 6,8 \\
\hline $\begin{array}{l}\text { CSI dizileri suç mağdurlarının } \\
\text { polisten beklentilerini değiştirdi. }\end{array}$ & 52 & 19,5 & 112 & 42,1 & 60 & 22,6 & 25 & 9,4 & 17 & 6,4 \\
\hline $\begin{array}{l}\text { CSI dizileri kamunun beklentilerinden } \\
\text { dolayı mahkemedeki/yargidaki } \\
\text { tutumumu etkiledi. }\end{array}$ & 23 & 8,3 & 52 & 19,5 & 96 & 36,1 & 63 & 23,7 & 33 & 12,4 \\
\hline $\begin{array}{l}\text { CSI dizileri suçlu davranışını etkiler } \\
\text { eğitimli failler yaratır. }\end{array}$ & 48 & 18,0 & 91 & 34,2 & 67 & 25,2 & 35 & 13,2 & 25 & 9,4 \\
\hline $\begin{array}{l}\text { Soruşturma evresinde CSI dizilerindeki } \\
\text { yöntemler yararlıdır ve kullanılabilir. }\end{array}$ & 24 & 9,0 & 84 & 31,6 & 85 & 32,0 & 55 & 20,7 & 18 & 6,8 \\
\hline $\begin{array}{l}\text { CSI dizileri polisin suç } \\
\text { soruşturmasının basit olduğunu } \\
\text { göstermektedir. }\end{array}$ & 34 & 12,8 & 62 & 23,3 & 63 & 23,7 & 81 & 30,5 & 26 & 9,8 \\
\hline $\begin{array}{l}\text { CSI dizileri hukuk sisteminin } \\
\text { işleyişinin basit olduğunu } \\
\text { göstermektedir. }\end{array}$ & 41 & 15,4 & 51 & 19,2 & 59 & 22,2 & 91 & 34,2 & 24 & 9,0 \\
\hline $\begin{array}{l}\text { CSI dizileri toplumda hukuk } \\
\text { sisteminin işleyişis ile ilgili yanlış } \\
\text { algıların oluşmasına yol açmaktadır. }\end{array}$ & 48 & 18,0 & 80 & 30,1 & 69 & 25,9 & 50 & 18,8 & 19 & 7,1 \\
\hline $\begin{array}{l}\text { CSI dizileri insanların hukuk sisteminin } \\
\text { işleyişini doğru şekilde anlamalarını } \\
\text { sağlamaktadır. }\end{array}$ & 19 & 7,1 & 49 & 18,4 & 91 & 34,2 & 71 & 26,7 & 36 & 13,5 \\
\hline $\begin{array}{l}\text { CSI dizileri soruşturma ve } \\
\text { kovuşturma evrelerini gerçeğe uygun } \\
\text { şekilde göstermektedir. }\end{array}$ & 19 & 7,1 & 39 & 14,7 & 89 & 33,5 & 76 & 28,6 & 43 & 16,2 \\
\hline $\begin{array}{l}\text { CSI dizileri olay yerinden delil } \\
\text { toplamayı aslına uygun olarak gösterir. }\end{array}$ & 18 & 6,8 & 72 & 27,1 & 80 & 30,1 & 74 & 27,8 & 22 & 8,3 \\
\hline $\begin{array}{l}\text { CSI dizilerinde olay yerinde bulunan } \\
\text { delillerin suçla olan ilişkisi ve } \\
\text { ulaşlabilen delil sayısı gerçek bir } \\
\text { olay yeri incelemeyi yansıtır. }\end{array}$ & 18 & 6,8 & 61 & 22,9 & 90 & 33,8 & 69 & 25,9 & 28 & 10,5 \\
\hline $\begin{array}{l}\text { Görevimi yaparken yada mesleğimin } \\
\text { ne olduğu öğrenildiğinde CSI izleyicisi } \\
\text { sade vatandaşlar sıklıkla akıl öğretmeye } \\
\text { kalkışıyorlar. }\end{array}$ & 45 & 16,9 & 77 & 28,9 & 72 & 27,1 & 51 & 19,2 & 21 & 7,9 \\
\hline $\begin{array}{l}\text { Bu dizilerin etkisi nedeniyle şüpheli } \\
\text { ve sanıkların olay yerinde eskisine } \\
\text { oranla daha az delil bıraktıklarını } \\
\text { düşünüyorum. }\end{array}$ & 48 & 18,0 & 78 & 29,3 & 66 & 24,8 & 55 & 20,7 & 19 & 7,1 \\
\hline
\end{tabular}


Katılımcıların yaklaşık yarıya yakını bu dizilerin etkisiyle şüpheli ve sanıkların olay yerinde eskisinden daha az delil bıraktıklarını düşünmektedir. Anketi yanıtlayanların 4'de 1'i bu konuda kararsız kalırken, 3'de 1'i ise bu görüşe katılmadıklarını beyan etmişlerdir (Tablo 2). Bu görüş hakkında olumlu düşünenlerin meslek gruplarına göre dağılımı incelendiğinde sırasıyla savcılar, polisler, hakimler, avukatlar ve adli tıp/ bilim uzmanlarının geldiği görülmektedir Şekil 3).

\section{Tartışma}

Günümüzde dördüncü güç olarak tanımlanan medyanın toplum üzerindeki etkisi birçok açıdan farklı araştırmalarla ele alınmıştır. Medyanın ve özellikle televizyonun toplumsal inançları etkileyebileceği görüşü uzun zamandan beri dile getirilmektedir (20). Bourdieu'ya göre "Televizyon, nüfusun çok büyük bir bölümünün zihinlerindeki tasarımların oluşturulmasında bir tür fiili tekele sahiptir." (21). Medya organlarının en güçlüsü olduğu varsayılan televizyondan sonra internet kullanımının yaygınlaşması, sinema ve dizi gibi birçok farklı yapıma izleyicinin televizyondan bağımsız olarak çeşitli kanallar üzerinden ulaşmasına imkan vermiştir.

Amerika Birleşik Devletleri'nde 2000'li yıllardan itibaren polisiye diziler adli bilimsel teknik ve yöntemleri de göz önünde bulundurarak içeriklerini hazırlamaya başlamışlardır. CSI ve benzeri dizilerin ekranlarda gördüğü ilgiye paralel olarak izleyicilerin adalet sisteminin işleyişi ve adalet sistemi profesyonellerinin yaptıkları işlerle ilgili gerçekte olduğundan daha farklı bir beklenti içine girdikleri birçok araştırma ile ortaya konulmuştur (19).

Araştırmamızda CSI ve benzeri dizileri izleyen çoğunluğun özellikle mesleki hayatlarına yeni başlamış ve 25 - 35 yaş diliminde olan adalet hizmeti çalışanları olduğu göze çarpmaktadır. Araştırmaya katılanlar tarafından en çok izlenen dizi Behzat Ç. iken, sıralamayı Kanıt, Arka Sokaklar ve Dexter takip etmektedir. Meslek gruplarına ayırarak en çok takip edilen dizilere bakıldığında polis memurlarının en çok Behzat Ç.'yi izledikleri tespit edilmiştir. Bu duruma neden olan en önemli faktörün dizinin genel içeriğinin kendi hayatlarına yakın olması ve kahramanla özdeşim kurabilmeleri olduğu düşünülmektedir. Öte yandan avukat, hakim ve savcıların daha çok Kanıt dizisini izlediği görülmüştür. Kanıt'ın kurgulanmış herhangi bir diziye kıyasla daha fazla gerçek olaylardan esinlenmesi ve programda olayların ele alınış biçiminin akademik yöntemler ve bilimsel incelemelere dayanmasının bu duruma etki eden en önemli faktör olduğu düşünülmektedir. Katılımcı adli bilimler uzmanları diğer meslek gruplarına kıyasla daha genç ve çevrim içi kanallar üzerinden dizi takip etme alışkanlığına sahip bir kitle olduğundan yabancı dizileri de takip ettikleri anlaşılmıştır. Adli bilim uzmanları ağırlıklı olarak Dexter izlemeyi tercih etmektedirler. Hem ülkemizde hem de yurtdışında oldukça ses getirmiş bu yapım, bugüne kadar yapılmış diziler içerisinde hem kahramanının hem de dizi senaryosunun alışılagelmiş CSI dizi kalıplarından farklı olması sebebiyle oldukça göze çarpmaktadır. Dizi kahramanın bir adli bilimler uzmanı olması bu meslek grubunun dikkatini çektiği düşünülmektedir.

Polis, hakim, savcı ve avukatlar, dizilerden etkilenen vatandaşların mesleklerini icra etmeleri esnasında işlerine müdahale ederek onlara akıl verdiklerini belirtmişlerdir. Özellikle polis memurları, araştırmamız esnasında, “Arka Sokaklar'da böyle olmuyor" tepkisiyle karşılaştıklarını sözel olarak da ifade etme ihtiyacı duymuşlardır. Oysa Arka Sokaklar isimli dizide suçun türünün ne olduğuna bakılmaksızın aynı polis ekibinin suç olayına müdahale etmesi, polisin silah kullanma ve dinleme yapma yetkisi gerçek uygulamalarla uyuşmamaktadır.

Araştırmamıza katılan tüm meslek grupları dizileri takip etmeseler dahi, CSI ve benzeri dizilerin etkisiyle toplumun mesleklerine olan ilgisinin arttığını belirtmişlerdir. Katılımcılar arasında meslek gruplarına göre kıyas yapıldığında en fazla, adli bilimler uzmanlarının bu fikre katıldığı saptanmıştır. Bu duruma dizilerin içeriğinin ağırlıklı olarak adli bilimler olmasının etkisinin büyük olduğu düşünülmektedir. Stinson, Patry ve Smith tarafından yapılan benzeri bir araştırmada 127 adli tıp uzmanının görüşü alınmış ve katılımcılar CSI ve benzeri dizilerin, toplumun adli süreçlere ilişkin genel ilgisini artırdığını belirtmiştir (19). Öte yandan Cole ve Diosovilla'ya göre CSI dizilerinin televizyonda yayınlanmasıyla birlikte adli bilimlerin popülerliği artmıştır. Aynı çalışmada araştırmacılar adli bilimler ile ilgili üniversite programlarına olan ilginin de arttığını belirtmişlerdir $(7,22,23)$. Bu durumun ülkemiz için de geçerli olduğu düşünülmektedir. Söz gelimi lisansüstü adli bilimler eğitiminin verildiği İstanbul Üniversitesi Adli Tıp Enstitüsü yüksek lisans ve doktora programlarına başvuranların sayısının artmasında CSI Etkisi'nin payı olduğu düşünülmektedir (24).

Araştırmamıza katılan her iki katılımcıdan birisi, kamunun çalışma alanlarıyla ilgili beklentilerinin CSI dizilerinden dolayı değiştiğini bildirmektedir. Meslek gruplarına göre incelendiğinde ağırlıklı olarak hakimlerin bu kanıda olduğu savcı, polis ve avukat gruplarının hakimleri takip ettiği ortaya çıkmaktadır. Stinson, Patry ve Smith tarafından gerçekleştirilen araştırmada katılımcıların neredeyse tümü CSI ve benzeri dizilerin kendi mesleklerine dönük toplumsal beklenti üzerinde etkili olduğunu belirtmişlerdir (19). Özellikle polis katılımcıların tümü CSI ve benzeri dizilerin polisin davranışlarıyla ilgili genel 
toplumsal beklentileri etkilediğini belirtmiştir. Katılımc1lara göre hem olay yerinden delil toplama ve inceleme konusunda, hem de olay yerinde bulunan delilin geçerliliği bakımından toplumsal farkındalık artmış ve bu durum toplumun kendilerinden beklentilerini etkilemiştir.

Bununla birlikte adalet sistemi çalışanlarına meslekleriyle ilgili uygulamaların CSI ve benzeri diziler yüzünden olumlu yönde etkilenip etkilenmediği sorusu yöneltildiğinde, her 10 katılımcıdan 3'ü katıldığını belirtmiştir. Konuyla ilgili farklı çalışmalarda, özellikle adli bilimlerin laboratuvarda çalışan katılımcıların büyük çoğunluğunun mesleki uygulamalarının söz konusu yapımlardan pozitif anlamda etkilendiğini dile getirmişlerdir (19).

Adli bilimler alanında yaşanan teknolojik gelişmelerin de konuyla yakından ilgili olduğu düşünülmektedir. Söz gelimi araştırmamızdan elde edilen bulgulara göre, adli sistem çalışanlarının neredeyse tamamı, yaşanan bilimsel ve teknolojik gelişmelerin suçların aydınlatılmasını olumlu yönde etkilediğini ifade etmişlerdir. Oysa Amerika Birleşik Devletleri'nde yürütülmekte olan Masumiyet Projesi'nin sonuçlarının analiz edildiği yakın tarihli bir araştırmada, hem alandaki hem laboratuvardaki tüm gelişmelere rağmen, her yıl yüzlerce kişinin bilimsel delillerin yanlış ya da eksik değerlendirilmesi nedeniyle haksız yere hüküm giydiğini ortaya koymuştur (16).

Araştırmamızda ele alınan bir diğer konu da CSI ve benzeri dizilerin suç işleyenler üzerindeki etkileridir. Her iki katılımcıdan biri CSI ve benzeri dizilerin etkisi nedeniyle şüpheli ve sanıkların olay yerinde eskiye oranla daha az delil bıraktıklarını düşündüklerini belirtmişlerdir. Diğer meslek gruplarına kıyasla özellikle olay yerinde görev alan savcı ve polislerin bu görüşü destekledikleri gözlemlenmiştir. Araştırmamızda "CSI ve benzeri dizilerin eğitimli failler yaratıp yaratamadığına" dair yöneltilen soruya verilen yanıtlardan yola çıkarak konunun bir başka boyutu ortaya konmaktadır. Her iki katılımcıdan birisi, söz konusu dizilerin suçluları nasıl yakalanmayacakları hakkında eğittiklerini düşünmektedir. Özellikle adli bilim uzmanları ve polisler bu görüşü desteklerken, söz edilen meslek gruplarının adalet sistemi içerisinde suçlu, mağdur ve olay yeri ile doğrudan temas etmelerinin buna neden olduğu varsayılmaktadır. Literatürde suçluların CSI ve benzeri dizilerden delilleri karartabilecek yöntemler öğrendiklerini ve profesyonelleştiklerini iddia eden çalışmalara rastlamak mümkündür (5).

Araştırmamızın bulgularına göre katılımcıların büyük çoğunluğu CSI ve benzeri dizilerde aktarılan soruşturma ve kovuşturma süreçlerinin aslına ne kadar uyumlu olduğu konusunda şüphededir. Ayrıca söz konusu dizilerde bir olay yerinden elde edilen delil sayısının gerçek bir olay yerinden elde edilen delil sayısından farklı olduğu düşünülmektedir. Her üç katılımcıdan yalnızca birisi söz konu- su programların, olay yerinden delil toplamayı aslına uygun olarak gösterdiğini ifade etmiştir. Literatürde de araştırmamızı destekler nitelikte çalışmalara rastlanmaktadır. Stinson, Patry ve Smith tarafından yapılan araştırmada katılımcıların çoğu soruşturma biçimleri ve delillerin geçerliliği açısından bu programları gerçekdışı bulduklarını belirtmişlerdir (19). Bunun yanı sıra katılımcıların büyük çoğunluğu delilin tanımlanma değeri açısından bu programları gerçekçi bulmaktadır. Phoenix, Maricopa Eyalet Savcılığı tarafından 2005 yılında yürütülen bir başka araştırmada, duruşma deneyimi olan 102 savcıya CSI Etkisiyle ilgili bir anket yöneltilmiştir. Araştırmaya katılan uzmanlar CSI'da gösterilen soruşturma tekniklerinin her zaman doğru olmadığını hatta bu teknikleri mantıklı bulmadıklarını ifade etmişlerdir (8).

CSI ve benzeri dizilerin içerikleri göz önünde bulundurulduğunda diğer bir tartışma konusu eğitimli faillerin yanı sıra bu yapımların eğitimli mağdurlar yaratıp yaratmadığı hakkındadır. Bu yapımların delillerin önemi ve korunmasıyla ilgili toplumsal bir farkındalık oluşturduğu aşikardır (25). Özellikle bu tür dizilerin, cinsel istismar mağdurlarına saldırıdan sonra yapmaları veya yapmamaları gereken eylemlerle ilgili önemli ve öğretici bir yol gösterici olabileceği düşünülmektedir. "Law and Order Special Victim Units" adlı yapım, dünya üzerinde konuyla ilgili yayınlanan önemli bir örnektir. Bu yapım, diğer yapımlara kıyasla içeriğinde özellikle cinsel istismar mağduru çocuklara, kadınlara ve mağdurun yaşadığı travmaya yer vermesiyle dikkat çekmektedir.

Tüm bu bulgular göz önüne alındığında; Türkiye'de son yıllarda gerçekleşen "Zonguldak Cinayeti" ve "Özgecan Cinayeti” gibi toplumsal infial yaratan olguların CSI Etkisinin doğrudan gözlemlenebileceği örnekler olduğu akla gelmektedir. Söz konusu iki olguda da faillerin sorgularında, olay yerinde bir takım delilleri ortadan kaldırmaya çalıştıklarına dair ifadelere rastlanmaktadır. Adli bilimler için mesleki sırların ifşası adına bu durum risk faktörü olarak değerlendirilebilmektedir. Bu bağlamda adli bilimlerin suçu aydınlatmada kullandığı yöntemlerin ne kadarının ekranda olması, ne kadarının mesleki, özel bir bilgi olarak kalması gerektiği sorularının bir kez daha düşünülmesinin yerinde olacağı öngörülmektedir.

\section{Sonuç}

Bu çalışmada literatürde CSI Etkisi (CSI Effect) olarak bilinen kavramın Türkiye'de adalet mekanizması ça1ışanlarında ne tür bir alg1 yarattığı araştırılmıştır. Araştırmada elde edilen bulgulara dayanarak; toplumun adalet mekanizmasından beklentilerinin değiştiğini söylemek mümkündür. Bununla birlikte adalet mekanizması çal1şanlarında CSI dizilerinin toplumu adalet mekanizması hakkında yanıltıcı bilgilendirdiği yönünde bir kanının 
oluşmuş olduğu görülmektedir. Bu durumun soruşturma ve kovuşturma süreçlerini yürüten profesyonelleri zor durumda bıraktığı anlaşılmaktadır.

CSI ve benzeri dizilerin suçlulara yöntem öğrettiği konusunda profesyonellerin hemfikir olduğu ortaya çıkmaktadır. Teorik olarak suçluyu eğitmek gibi bir misyon üstlenmemiş olsalar da, bu yapımların pratikte faili eğitici bir rol üstlenme riski taşıdığı iddia edilmektedir.

Suç, toplumsal bir olgudur ancak suçun aydınlatılması ve önlenmesi profesyonellik gerektiren bir çabadır. Elbette teknik ve bilimsel gelişmelerin toplumdan saklanması mümkün değildir. Bu dizilerin toplumun adalet sisteminden beklentisini yükseltmesiyle ve potansiyel suçlulara yöntem öğretmesiyle ortaya çıktığı düşünülen olumsuzlukların, senaryolarda mağduru korumaya yönelik ve adli süreç hakkında bilgilendirme gibi içeriklere de yer verilerek olumlu hale dönüştürülmesi önerilmektedir. Öte yandan CSI ve benzeri yapımlarda gösterilen yöntem ve kullanılan teknolojinin, ülkemizdeki uygulamalar ile kıyasının başka bir araştırma kapsamında ele alınarak, gerçek ve kurgu arasındaki farkların daha iyi gözlemlenmesinin yerinde olacağı düşünülmektedir.

\section{Kaynaklar}

1. Kakınç TD. 100 Filmde Başlangıcından Günümüze Gerilim/ Polisiye Filmleri. 1st ed. Istanbul: Bilgi Yayınevi; 1995. p. 11.

2. Willing, R. "CSI Effect" Has Juries Wanting More Evidence [Internet]. USA Today; 2004. [updated 8/5/2004; cited 2016 March 9] Available from: http://usatoday30.usatoday.com/ news/nation/2004-08-05-csi-effect_x.htm

3. Shelton DE. The'CSI Effect': Does It Really Exist? National Institute of Justice Journal [Internet]. 2008; 259:[1-7 pp.]. Available from: http://ssrn.com/abstract=1163231.

4. Cole SA, Dioso-Villa R. Investigating the'CSI Effect'Effect: Media and Litigation Crisis in Criminal Law. Stanford Law Review [Internet]. 2009 [cited 2016 March 9]; 61(6):[133574 pp.]. Available from: http://ssrn.com/abstract=1401417.

5. Durnal EW. Crime scene investigation (as seen on TV). Forensic Sci Int. 2010;199(1-3):1-5. doi: 10.1016/j. forsciint.2010.02.015.

6. Shelton DE. Juror expectations for scientific evidence in criminal cases: Perceptions and reality about the CSI effect myth. TM Cooley L Rev [Internet]. 2010 [cited 2016 March 9]; 27(1). Available from: http://heinonline. org/HOL/Page?handle=hein.journals/tmclr27\&div=4\&g sent $=1 \&$ collection $=$ journals

7. Cole SA, Dioso-Villa R. CSI and its Effects: Media, Juries, and the Burden of Proof. New England Law Review. 2007;41(3):435-69. Available from: http://ssrn.com/ abstract $=1023258$.

8. Heinrick J. Everyone's an expert: The CSI effect's negative impact on juries. The Triple Helix [Internet]. 2006; 3(1): [5961 pp.]. Available from: http://citeseerx.ist.psu.edu/viewdoc/ download?doi=10.1.1.560.4445\&rep=rep1\&type $=$ pdf.
9. Tyler TR. Viewing CSI and the Threshold of Guilt: Managing Truth and Justice in Reality and Fiction. The Yale Law Journal. 2006;115(5):1050. doi: 10.2307/20455645.

10. Thomas AP. The CSI effect: fact or fiction. Yale LJ Pocket Part 70 [Internet]. 2006 [cited 2016 March 9]; 115. Available from: http://www.yalelawjournal.org/forum/the-csi-effectfact-or-fiction.

11. Dorfman L, Schiraldi V. Off Balance: Youth, Race \& Crime in the News. Building Blocks for Youth. Washington: Youth Law Center, 2001. [cited 2016 March 9]. Available from: http://www.justicepolicy.org/images/upload/01-04_REP_ OffBalanceNews_JJ-RD.pdf.

12. Cooley CM. CSI Effect: Its Impact and Potential Concerns, The. New Eng L Rev. 2006;41:471-501. Available from: http://www.nesl.edu/userfiles/file/lawreview/Vol41/3/ Volume \%2041,\%20book\%203,\%20article\%202.pdf.

13. Deutsch SK, Cavender G. CSI and forensic realism. Journal of Criminal Justice and Popular Culture. 2008;15(1):34-53. Available from: http://www.albany.edu/scj/jcjpc/vol15is1/ Deutsch_Cavender.pdf.

14. Bergslien E. Teaching To Avoid the "CSI Effect". Keeping the Science in Forensic Science. Journal of Chemical Education. 2006;83(5):690. doi: 10.1021/ed083p690.

15. Houck MM. CSI: Reality. Scientific American. 2006;295(1):84-9. doi: 10.1038/scientificamerican0706-84.

16. Turvey BE, Cooley CM. Forensic Science, The CSI Effect, and Wrongful Convictions. Miscarriages of justice: actual innocence, forensic evidence, and the law. Kidlington, Oxford, UK: Academic Press; 2014. p. 171-96.

17. VanLaerhoven S, Anderson G. The Science and Careers of CSI. In: Byers M, Johnson VM, editors. The CSI effect: Television, crime, and governance. Critical studies in television. Lanham: Lexington Books; 2009. p. 29-60.

18. 'Kesik El Cinayeti' davası başlıyor. Istanbul: Sabah Gazetesi; 2014 [updated 2014 April 7; cited 2016 March 9]. Available from: http://www.sabah.com.tr/yasam/2014/04/07/kesik-elcinayeti-davasinda-ilk-durusma-22-nisanda

19. Stinson V, Patry MW, Smith SM. The CSI effect: Reflections from police and forensic investigators. The Canadian Journal of Police and Security Services. 2007;5(3):12533. Available from: http://smu-facweb.smu.ca/ mpatry/ Stinsonetal07.pdf

20. Postman N, Akınhay O. Televizyon: öldüren eğlence: gösteri çağında kamusal söylem. 5th ed. Istanbul: Ayrıntı Yayınlar1; 2014. p. 38.

21. Bourdieu P. Televizyon Üzerine. (T. Ilgaz, Trans.). Istanbul: Yap1 Kredi Yayınları; 1997. p. 23.

22. McManus SE. Influence Of The Csi Effect On Education And Mass Media. [master's thesis].[Orlando (FL)]: University of CentralFlorida;2008.150p.Availablefrom:http://stars.library. ucf.edu/cgi/viewcontent.cgi? article $=2576 \&$ context $=$ etd

23. Catalani R. A CSI Writer on the CSI Effect. Yale LJ Pocket Part. 2006;115:76-8.

24. Ziyalar N, Ersoy G, Açıkkol M, editors. Türkiye'de Adli Bilimler Lisans Üstü Eğitim Programları. XII Adli Bilimler Kongresi; 2015; Isparta.

25. Marsh I, Melville G. Crime, justice and the media. London; Routledge; 2009. viii, 206 p. 